\title{
PSYCHO-ADMINISTRATIVE DETERMINANTS FOR CHOICE OF PHYSICAL EDUCATION AMONG SENIOR SECONDARY SCHOOL STUDENTS AT EXTERNAL EXAMINATION BODIES
}

\author{
Babatunde Samson Olusola \\ Department of Human Kinetics and Health Education, Faculty of Education, University of Lagos
}

UDK 796.01:159.9:373.3/.4

\section{SUMMARY}

Empirical observations reveal low enrolment of senior secondary school students for physical education at external examination bodies. The poor rate of students' choice of the subject at this level is a matter of concern to professionals, given the fact of monumental benefits of physical education as a science subject to humanity. The study was conducted to examine how psycho-administrative factors influence the choice of physical education by senior secondary school students at external examination bodies (in Nigeria) to come up with modalities to increase enrolment of the subject at external examination bodies. Descriptive method was applied for the study due to large respondents involved. Self-developed validated questionnaire tagged psycho-administrative determinants for choice of physical education among senior secondary school students at external examination bodies (PADGPEAS) was applied for the research. Out of three thousand and twenty-four (3024) questionnaire forms administered, only two thousand and fifty (2950) copies completed and returned were coded for analysis, with the use of descriptive statistics of percentages and nonparametric statistics of Chi-square $\left(\mathrm{x}^{2}\right)$ at 0.05 level of significant. Results unraveled a remarkable influence of psycho-administrative variables on the choice at physical education among senior secondary school students at external examination bodies. Based on this outcome, it is suggested that utilization of variety of methods by physical education teachers will go a long way to kindle the interest of the students for the subject. Enlightenment of students and parents on the values of physical education will facilitate remarkable positive attitude of both parts that relocate their position in favor of the subject.

Keywords: Teacher's problem, student's interest, parental influence, physical education, senior secondary school students 


\section{INTRODUCTION}

Physical education is globally recognized as an invaluable part of every school curriculum. One of the objectives of physical education is to instill in the student the values and skills of maintaining healthy lifestyle. Daily physical activity promotes an awareness of health and wellbeing among students. Physical education (PE) assists the recipients to cultivate the habit of a healthy life in adulthood. PE as a viral subject constitutes programme geared towards promotion of physical fitness in students, trains them in sports, assists them understand rules and strategies in playing and instruct them the beauty inherent in working as a team. A very crucial factor in physical education according to Omolawon (2000) is the development of interpersonal skills in students. Sports aim at making the students team players, developing a sportsman spirit in them and as well enhancing their competitive spirit. Babatunde (2003) reported that students in secondary schools by the nature often create greater interest in creative subject live physical education if the subject is well planned and sold to the students in a systematic procedure. Onifade (2001) and Babatunde (2002) are of the opinion that physical education in secondary school as academic discipline as well as professional venture will go at length in reducing incidence of absenteeism and dropouts among the students.

PE as a complementary education, Dosunmu (2001) indicated that it should by necessity be provided for in school curricular for complete learners' education. Adedoja (1986) and Babatunde (2011) advocated for psychological research in connection with the motivational orientations and dispositions of students towards PE in Nigerian educational system, senior secondary school in particular. To achieve the participation goal of physical education programmes at senior secondary level, an accurate knowledge of psychological needs and desires of the participants and potential participants cannot be safely overlooked so as to accurately achieve basis for the development at appropriate participation and motivational strategies. Atufe (2012) maintained that PE contributes to the development of the total personality of an individual including the development of social, psychological, intellectual, emotional, and physical traits. This reveal that $\mathrm{PE}$ has intellectual contribution for the beneficiaries which suggests that Senior Secondary School Student (SSSS) are expected to create interest in offering it at external examinations bodies.

Interestingly and most paradoxically, observations have shown that insignificant number of SSSS students enroll for physical education write the subject at external examination bodies yearly. Babatunde (2015) revealed that most of candidates admitted to Department of Human Kinetics yearly do not offer $\mathrm{PE}$ at either west Africa examination council (WAEC) or National Examination Council (NECO). Babatunde (2001), noted that substantial number of candidates applied to Department of Human Kinetics and Health Education are mostly those 
who offered sciences like physics, chemistry or biology but not even physical education or health education. The effect of this according to Adejuyigbe, Adejuyibe (1016) is that most candidates do not often possess physical education background, which has negative consequences on the quality of academic readiness for the course. Atufe (2012) exposed that for PE to be transformed and sustained; its practice must begin from elementary through secondary school. Babatunde and Ogundipe (2006) averred that to achieve meaningful success of PE pursuit in tertiary institutions eligibility and requirement include credit in PE either at WAEC or NECO and other similar external examination bodies designed for the purpose admission into tertiary institution. This according to Lawal (2011) will in greater measure to facilitate smooth transition of candidates admitted for the course for the course. For sound footing of any academic discipline, Atufe (2012), Idehen and Cehodin (2008) recommended that for admission of prospective candidates, credit in PE at external examination bodies should form the parameter for consideration, especially in specialized disciplines like PE.

Enrolment for or choice of subjects at external examinations bodies such WAEC, NECO and a host of others in Nigeria is governed by avalanche of factors among SSSS. The multitudes of factors that impact upon students' decision are both extrinsic and intrinsic. The intrinsic aspect of the choice of subjects is related to students' interest, self-perception, and aspiration in terms of future career and understanding of the usability of such subject. Joanne, Daniel, Alison (2015). Babatunde (2006), found that young people want a respected profession and have the courage and fortitude to be standard bearers for their convictions. In the same vein, Babatunde (2003) and Toanne, Daniel Alison (2015) noted that interest of the students and capability are strong pillars for the choice of subjects among SSSS I due to the fact that interest sustains conviction, meaning that what interest one, will be sustained and pursued.

However, in another dimension, students' decision making on subjects to be registered enrolled for is determined by external factors due to many intervening variables like parents, school counselor, and in many cases peer group. Ian Hugh (2012) observed that choice of subjects by SSSS is dictated by parents inasmuch as they are economically dependent on parents, coupled with their maturity level. This position, therefore, according to Babatunde (2002) buttresses that why student reliant on their parents for making decisions, especially on the future careers, including educational activities. Toanne, Daniel, Alison (2015) reported significant parental influence on SSSS choice of subjects.

Teachers as role model play tremendous impact in students' decision making as relates to subject selection among SSSS. Idehen and Oshodin (2008), Adejuyigbe and Adejuyigbe (7016) found that the role of teacher in subjects' selection SSSS could not be safely ignored as they are acting into in-loco-parentis by assuming and discharging the obligation of parent to the students. in choice career, Babatunde (2003) opined that teachers are at the vantage position in 
convincing SSSS in selecting subject combination that meets their career aspirations a mark of respect for them as teacher. Research evidence like Atife (2012), Idenhen and Oshodin (2008) affirmed strong reliance of SSSS on teachers for subject combinations relating to future academic aspiration.

Literature pertaining to SSSS' subject's selection according Toanne, Daniel, Alison (2015) recognized variety of factors that impact upon this decision such as extrinsic and intrinsic, are often acknowledged as co-existing highlighting an inter-relatedness of potential influences which can facilitate the prediction of specific subject up take in students. Brown (2010) suggeste that school subjects selected for study and occupational choices may be mutually reinforcing, and it is justified to posit that subjects chosen for option study may limit or promote future direction. The extrinsic factor as associated with teachers attitudes subject presentation forms a solid motivational strategy to kindle or lure students' interest for enrolment of students at SSSS for a particular subject. Omokwon (2001) mentioned that students being the central concern of the school in the educational process are influenced in no small way by the efficiency and effectiveness of the working staff (teachers) in the performance of their duties. Babatunde (2001) remarked that the place of subject teachers in attracting luring students to select their subjects at external examination bodies is noteworthy. In similar vein, Idehen and Oshodin (2008) concluded that teacher related problems affect enrolment for health, which by projection can apply to PE.

The inception of PE in Nigerian tertiary institutions witnessed emergence of courses like certificate and diploma programs in PE so as to dovetail to degree level in order to meet up with quota not minding their ordinary level papers are related. According to Babatunde and Asagba (2011), most of the students considered for admission to the department of physical and health education/ human kinetics and health are not often applied for the course but drifted to the department to fill the quota by university managements.

\section{RESEARCH HYPOTHESES}

1. Teacher's attitude would not significantly influence the choice of physical education among SSSS at external examination bodies.

2. Parental influence would not be a significant determinant for the choice of physical education at external examination bodies among SSSS.

3. Students' interest would not be a significant variable for the choice of physical education among SSSS at any external examination bodies. 


\section{ALTERNATIVE HYPOTHESES}

1. Teacher's attitude would significantly influence the choice of physical education among SSSS at external examination bodies.

2. Parental influence would be a significant determinant for the choice of physical education at external examination bodies among SSSS.

3. Students' interest would be a significant variable for the choice of physical education among SSSS at any external examination bodies.

\section{METHOD AND PROCEDURE}

The research was conducted to examine those factors that determine SSSS choice of PE at external examination bodies, with a view to strategizing modalities for positive change of SSSS towards the subject. The method used for the study was descriptive survey due to the fact that large number of respondents was involved. The suitability of this method for the study is this it appropriate for decision-making on the data obtained from a large population for generalization and objective prediction.

Self-developed questionnaire christened psycho-administrative determinants for choice of Physical Education Among Senior Secondary School Students at External Examination Bodies (PADGPEAS). The instrument is fashioned after modified Likert scaling of Strongly Agreed $(S A)=4$ points, Agreed $(A)=3$ points, Disagreed $(D)=2$ points and strongly Disagreed $(S D)=1$ points. Test - retest was applied for the reliability of the questionnaire, which gave the value of 0.89 , and a concomitant validity by experts.

Eighty-four (84) respondents were sampled from each of the thirty-six (36) states; making three thousand and twenty-four $(3,024)$ respondents; comprising school principals, vice principals parents, PE teachers and SSSS, thirty - six (36) trained research assistants, one for each state assisted in the administration of the questionnaire. Out of $(3,024)$ copies of the instrument administered, two thousand, nine hundred and thirty $(2,950)$ correctly filled and returned which is $96.96 \%$ return rate were coded for analysis, using descriptive statistics of percentages and inferential statistics of chi-square $x^{2}$ at 0.05 alpha level.

\section{DATA PRESENTATION AND DISCUSSION}

Table 1 gives a vivid empirical information on influence of teachers' attitude on the choice of SSSS for PE at external examination bodies such a WAEC, NECO, NABTED to mention but few. Chi-square $x^{2}$ as shown from the table is greater than 
the critical value. This position beyond doubt depicts that the hypothesis which started that teachers, attitude would not influence the choice of PE among SSSS at external examination bodies is rejected. This outcome affirms the finding of Babatunde (2015) that students' interest for PE at (SSS) is ignited by the subject teacher. In the same vein, Idenen and Oshodin (2008) maintained that subject teacher's role cannot be undermined in the choice of subject at (SSS) level.

Table 1. Chi- square table of teacher's attitude

\begin{tabular}{|l|c|c|c|c|c|}
\hline Responses & Frequencies & $\begin{array}{c}\text { Frequencies } \\
\%\end{array}$ & $\mathbf{x}^{\mathbf{2}}$ & Agreement & Remark \\
\hline S.A & 993 & 33.64 & & & \\
\hline A & 1,123 & 38.09 & & 71.73 & Significant \\
\hline D & 520 & 17.63 & 159.33 & 28.27 & \\
\hline S.D & 314 & 10.63 & & & \\
\hline & 2,950 & 100 & & 100 & \\
\hline
\end{tabular}

Chi-square value $=159.33 ; \mathrm{d} . \mathrm{f}=3 ; \mathrm{p}=0.05$; Table value 7.815 ; hypothesis significant.

Table 2. Chi-square table parental influence

\begin{tabular}{|l|c|c|c|c|c|}
\hline Responses & Frequencies & $\begin{array}{c}\text { Frequencies } \\
\%\end{array}$ & $\mathbf{x}^{\mathbf{2}}$ & Agreement & Remark \\
\hline S.A & 1093 & 37.06 & & & \\
\hline A & 1224 & 41.49 & 206.24 & 78.55 & Significant \\
\hline D & 419 & 14.20 & & 21.45 & \\
\hline S.D & 214 & 7.25 & & & \\
\hline Total & 2950 & 100 & & 100 & \\
\hline
\end{tabular}

Chi-square value $=206.24 ; \mathrm{df}=3 \mathrm{p}=0.05$; table 7.815 ; hypothesis: significant

Parental influence according Babatunde (2002) is a solid factor which dictates the line of action of the wade, particularly academic and career selection. Table 2 reveals empirical data of parental influence on PE selection among SSSS at external examinations bodies. The chi-square of 206.24 is bigger than the critical value 7.815. With this result, it is concluded that parents exert strong impact on the selection of subjects to be offered by SSSS, particularly at external examination bodies, with a view to prevent error of subjects' selection that may likely culminate into problem for appropriate future career. Toanne, Daniel, Alison (1915) elucidated that parents religiously as well as assiduously guide their wards the track or steps to follow so as to be useful in life. Babatunde (2002) is of the opinion that parental guidance is of necessity to forestall irredeemable problem that could arise from lack of sense of realities associated withtheir level 
of maturity. Among factors that affect choice of subjects by SSSS at external examination bodies according to Idehen and Oshodin (2008) is teacher related problems in terms of bad presentation of the subject, unfriendliness and inadequate knowledge of the subject.

Table 3. Chi-square table of students' interest

\begin{tabular}{|l|c|c|c|c|c|}
\hline Responses & Frequencies & $\begin{array}{c}\text { Frequencies } \\
\%\end{array}$ & $\mathbf{x}^{\mathbf{2}}$ & Agreement & Remark \\
\hline S.A & 790 & 27.79 & & & \\
\hline A & 1326 & 44.94 & 35.604 & 72.73 & Significant \\
\hline D & 310 & 9.51 & & & \\
\hline S.D & 524 & 17.76 & & 27.27 & \\
\hline Total & 2950 & 100 & & 100 & \\
\hline
\end{tabular}

Chi-square value $=35.604 ; \mathrm{df}=3 ; \mathrm{p}=0.05 ;$ Table value $=7.815$; hypothesis: Significant

Success in any human endeavor as found by Babatunde (2017) is partly dependent on intrinsic interest; whatever stimulus is centered around will be promoted and sustained. Table 3 concerns itself with statistical analysis of students' interest as a factor for the choice of subjects at external examination bodies. The obtained $\left(\mathrm{x}^{2}\right)$ value as provided in the table is significantly higher than the table value, meaning that the interest of students dictates in greater measure the choice PE among SSSS and enrolment for it at external examination bodies, Toanne, Daniel, Alison (2015) found interests, needs and value as strong factors for the choice of subjects and career among SSSS. Atufe (2012) discovered lack of students' interest for PE at senior secondary school level is clog in the wheel of progress of the subject, a situation precipitated due to misconception formed about the subject value it enhances humanity. Babatunde (2003, 2015), Babatunde and Ogundipe (2006) and Babatunde (2017) in related study, justified the indispensable role of intrinsically generated interest of student in career selection.

\section{CONCLUSIONS}

The focus the study is on the investigation and analysis of the factors influencing the choice of PE among senior secondary school students at external examination bodies like (WAEC), (NECO) and NABTED, with a view to proffering recommendations for improving of choices of the subject among SSSS at examination bodies. Based on the results obtained on the study, the following are concluded:

1. The attitude of PE teachers at senior secondary school strata is a captious variable in the choice of PE among SSSS. 
2. Impact of parents on the choice of PE among SSSS is a noteworthy factor.

3. Personal interest of SSSS is found to be one of the major obstacles for the choice of PE at senior secondary school strata.

\section{RECOMMENDATIONS}

Research activities are essentially undertaken to finding out problems militating against social ventures such business, politics, education and a host of others so as to offer suggestions capable of resolving or attenuating such impediments. On this premise, the following are suggested, for positive attitude of SSSS toward PE at external examination bodies.

1. PE teachers in secondary schools be it junior or senior stratum adjured to adopt and utilize combination of methods in the presentation of the subject in order to elicit the interest of the students for the subject. The incontestable role of the teacher in igniting the students' interest toward the subject demands the usage of available of relevant methods during instruction as motivational strategy.

2. Being versed in the subject area as well and friendliness to the students will conventionally and unimaginably lure more students to choose the subject at both junior and senior Secondary School level.

3. Young people like senior secondary school students want a respected as well as recognized profession, assurance and enlightenment of students about role of PE in form of diverse future career opportunities will tremendously register the interest for it.

4. There is urgent need for the school management during parentsteachers' association meeting to enlighten the parents on the importance of PE for holistic development of humanity in terms numerous values such as varied career opportunities, enhancement of health and means of positive socialization as well as community integration. This awareness exercise serves as leverage that can be helpful to correct already misconception about PE by parents and students and hitherto translate to more SSSS enrolment for the subject at external examination bodies.

5. Appointment of reasoned, knowledgeable, and enthusiastic qualified PE teachers into senior secondary schools is of necessity to sensitize more SSSS to offer the PE at external examination bodies. This will greatly prevent admitting "adapted" candidates who have no interest in the discipline. 


\section{REFERENCES}

1. Adedoja, T. A. (1986). Sports excellence in Nigerian Universities: Participation, Motivation and research. Organisation of sports in Nigerian Universities: Proceedings of Grimness, NUGA 86 sports chic.

2. Adejuyigbe, S. 0 and Adejugbe, S. B. (2016). The Nigerian National Senior Secondary Schools Curriculum and its implications for Admission into Universities. Journal of Emerging Trends in Education Research and Police Studies (JETERAPS): 234-241.

3. Atufe, U. (2012).Re-engineering Physical Education for Employment and Employment and Self-Productivity in Nigeria. Knowledge Review 2614).

4. Babatunde, S. O. (2001). The values of sports as perceived by undergraduates in first Nigerian Universities, Nigerian Journal of Emotional Psychology 3.

5. Babatunde, S. O. (2002). School sports as an adjunct to UBE programme. African Journal of Croos- Cultural Psychology and sport Facilitation, 4.

6. Babatunde, S. O. (2003). Sports as an essential tool for effective primary education in Nigeria.Nigerian Journal of Emotional Psychology and Sports Ethics (NIJEPSE), 5,42-46

7. Babatunde, S. O. (2004). Selected Administrative ingredient for sport culture in Nigerian Universities, African Journal of Groups -cultural Psychology and sport facilitation, 6, 63-67.

8. Babatunde, S. O. and Ogundipe, F. (2006). Enhancing quality of life through recreation.Journal of International Council for Health, Physical Education, Recreation, sports and Dance, 1(2), 146-151.

9. Babatunde, S. O. (2011). Administrative strategies for promotion sports among female secondary school teaching staff in Ibadan metropolis. Contemporary Issues in Education, Health and sports: The way forward, Book of Reading in honor of Prof. J. A. Ajala, p. 542 - 551.

10. Babatunde, S. O. (2015). Enhancing qualify of life through participation in sports. Educational theory and practice AGOSS Disciplines in Movenkola, O. A, Kolande, C. O. 0; Asagba, B. O. Osiki, Jaiyoba A. (Eds.), p. 356 - 370.

11. Broun, C. A. (2010). Can legislation reduce gender differences in subject choice? A survey GCSE and level entries between 1970 and 1995 Educational Studies, 27, 173-186.

12. Dosummu, S. (2001).Towards an understanding of the sociology of sports. In Onifacts, A and Dosunmu, C. (eds), Emergent issues in the sociology of sports, Lagos, virtues consultancy pp. 4-5.

13. Idehen, C. O. and Oshohin, O. G. (2008).Factors Affecting Health instruction in Secondary Schools in Edo State, Nigeria. Department of Health, Environmental, Education and Human Kinetics .Ethro Med, 2 (1):61-66.

14. Joanne, V., Daniel, B; Alison, R. (2915).Factors Influencing Subject Selection in Upper Education (Key Stage 4) for males and females in England. Current Issues in personality Psychology, 3(3), 166-174.

15. Omolawon, K. O. (2000). Parameters Influencing the propagation of physical education and sports programs in Nigeria schools. the proceedings of the $1^{\text {st }}$ ICHPER. SD, African Regional conference, $37-40$. 
16. Yazid, L. I. (2014). Sport development; the Nigerian way: A review: International Journal of Physical Education, Sports and Health. CIJPESH, 1(4): 20-24.

\title{
ПСИХОЛОГО-АДМИНИСТРАТИВНЫЕ ДЕТЕРМИНАНТЫ ВЫБОРА СТАРШЕКЛАССНИКАМИ ЗАНЯТИЯ ФИЗИЧЕСКОЙ КУЛЬТУРОЙ
}

\begin{abstract}
АННОТАЦИЯ
Эмпирические наблюдения показывают низкий охват учащихся старших классов средней школы физическим воспитанием на внешних экзаменах. Низкий уровень выбора учащимися этого предмета на данном уровне вызывает озабоченность специалистов, учитывая огромную пользу физического воспитания как научного предмета для человечества. Исследование было проведено с целью изучить как психологоадминистративные факторы влияют на выбор физического воспитания учащимися старших классов средней школы на внешних экзаменационных комиссиях (в Нигерии), чтобы разработать методы увеличения набора по этому предмету на внешних экзаменационных комиссиях. В связи с большим количеством респондентов в исследовании был применен описательный метод. Для исследования был использован самостоятельно разработанный валидированный вопросник с тегами психолого-административных детерминант выбора физического воспитания среди учащихся старших классов средней школы на внешних экзаменах (PADGPEAS). Из трех тысяч двадцати четырех (3024) примененных форм анкеты, только две тысячи пятьдесят (2950) заполненных и возвращенных экземпляров были закодированы для анализа с использованием описательной статистики процентов и непараметрической статистики Чи-квадрат (х2) при уровне значимости 0,05. Результаты выявили значительное влияние психологоуправленческих переменных на выбор физического воспитания среди учащихся старших классов средней школы на внешних экзаменационных экзаменах. Исходя из этих результатов, можно предположить, что использование учителями физической культуры разнообразных методов поможет повысить интерес учащихся к этому предмету. Убеждение учащихся и родителей в ценности физического воспитания будет способствовать заметному положительному отношению обеих сторон, что изменит их позицию в пользу предмета.
\end{abstract}

Ключевые слова: Проблема учителя, интерес ученика, влияние родителей, физическое воспитание, учащиеся старших классов средней школы. 